Caderno Seminal Digital

\title{
QUERÔ: DISTORÇÕES E ESPELHAMENTO
}

André Luís Gomes*

Helciclever Barros da Silva Vitoriano**

Resumo: A partir da temática "especular", apresentamos, sob alguns ângulos, uma análise do romance Querô - uma reportagem maldita, publicado em 1976, adaptado pelo próprio autor, Plínio Marcos, para o teatro em 1979 e transmutado para o cinema em 2006 sob a direção de Carlos Cortez e roteiro de Bráulio Mantovani e Luiz Bolognesi. Nosso objetivo é discutir o romance e, sobretudo, a peça teatral de Plínio Marcos como obra proponente, ou seja, texto que traz no não dito, nas rubricas, nas falas, propostas para transposições fílmicas.

Palavras-chave: Teatro Brasileiro; Cinema; Plínio Marcos; Querô; espelhamento; Adaptação.

Abstract: From the theme "speculate", we bring forward an analysis of the novel Querô uma reportagem maldita, published in 1976, adapted by the author, Plinio Marcos, to the theater in 1979 and transmuted into a film in 2006 under the Carlos Cortez direction and screenplay by Braulio Mantovani and Luiz Bolognesi. Our intention is to discuss the novel and, especially, the play as a proponent text

Doutor em Literatura Brasileira pela Universidade de São Paulo USP

** Mestre em Literatura e Práticas Sociais pela Universidade de Brasília - UnB

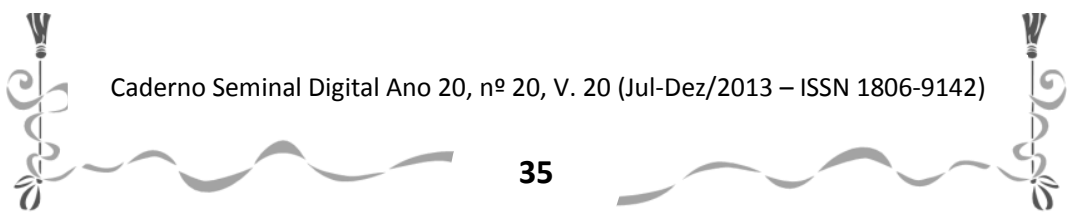


Caderno Seminal Digital

in other words, text that brings under the unsaid, in the headings theater, and theatrical speeches proposals for filmic transpositions.

keywords: Brazilian theater, cinema, Plínio Marcos, Querô, mirroring, Adaptation.

\section{INTRODUÇÃO}

Os espelhos e seus desdobramentos temáticos são uma tônica na literatura mundial praticamente em todas as suas fases e gêneros. Da poesia, passando pelo conto, romance e teatro, eles sempre se fizeram presentes na composição secundária ou primária de obras várias e, além disso, serviu de grande fonte para os estudos psicanalíticos, que não será nossa diretriz para a análise do romance Quero uma reportagem maldita, de Plínio Marcos, transmutado para o teatro e cinema ${ }^{2}$.

$\mathrm{Na}$ mesma esteira de ideias, o cinema se apropriou bastante deste objeto enquanto temática e construção de cenas - sendo ele próprio uma espécie de espelho ${ }^{3}$ : aquele que espelha a realidade e, no caso específico, aquele que espelha o romance e/ou o texto teatral através da transmutação, adaptação ou transcriação do texto fonte, ou

${ }^{2}$ A película em comento é Querô. Direção: Carlos Cortez. Brasil. 2006, 90 min. Colorido.

${ }^{3} \mathrm{O}$ exemplo mais recente é o filme Cisne Negro (2010). Direção de Darren Aronofsky que rendeu Oscar de melhor atriz à Natalie Portman. $O$ viés do duplo ligado à psicanálise é patente nesta obra. Ainda a respeito da natureza especular do cinema.

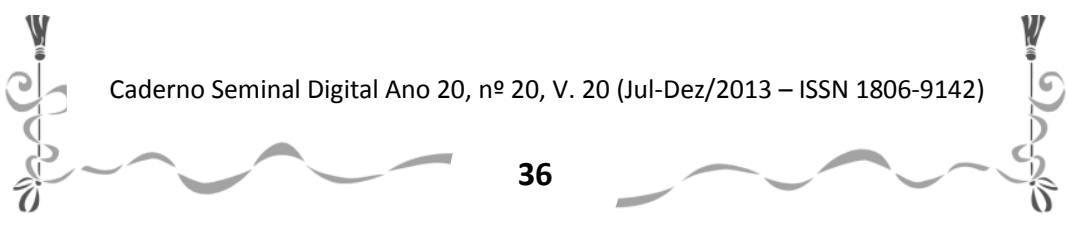


seja, a adaptação sendo pensada, numa linguagem metafórica, como espelhamento da obra, considerando todas as variações que temos desse objeto (côncavo, convexo, não reversivo, de duas direções, acústico) e de como ele pode ser posicionado/utilizado (frente a frente, quebrados e até na forma caleidoscópica). Genette (1972, p.23-24) traz esta mesma orientação crítica e ainda acrescenta os desdobramentos temáticos invariavelmente ligados à questão do espelho de Narciso, como é o caso da alteridade.

Esse objeto refletor tem, basicamente, duas funções antagônicas entre si: refletir a realidade e dar vida ao maravilhoso e ao fantástico. Sobre a magia dos espelhos, Eliza Ferreira (2001) nos esclarece semanticamente os vínculos de "miroir" (espelho) e "merveilleux" (maravilha) (2001, p.42). E essas funções foram exploradas por grandes clássicos infantis, basta lembrarmos-nos da clássica pergunta feita ao espelho mágico que não "mente" no conto A Branca de Neve pela madrasta (GRIMM; GRIMM, 1996) ou de Alice que viaja através do espelho (CARROLL, 1960). Há de se considerar ainda, o olhar do outro como espelho, como representação da relação eu-outro, do dialogismo que marca a interação entre um ser humano com outro ser humano e dos seres humanos com o mundo, considerando ainda que a imagem refletida no espelho é uma construção social. Percebemos esta função especular de modo cristalino na peça Entre quatro paredes (1944) de Sartre, no instante em que Inês se propõe a ser o

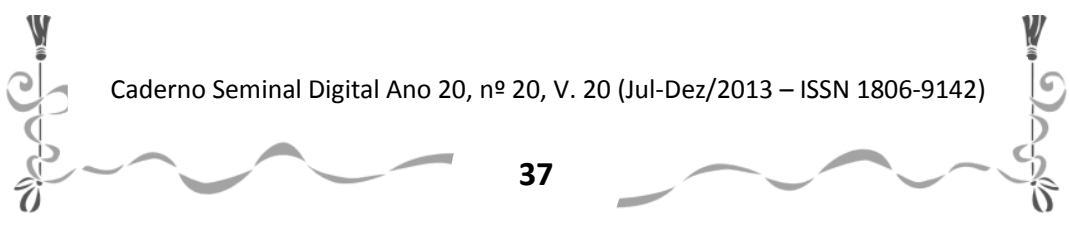


Caderno Seminal Digital

Â

espelho físico, oferecendo seus olhos, reflexo "ocular", de Estelle (Voulez-vous que je vous serve de miroir ? Venez, je vous invite chez moi. Asseyez-vous sur mon canapé. ${ }^{4}$ )

\section{PLÍNIO E O TEATRO-ESPELHO DA EXCLUSÃO}

Plínio Marcos foi um ser inquieto e irresoluto que não se deixava vencer pela opinião da maioria, que estava em constante mutação de si mesmo e almejava isso para os demais seres humanos. Que, pretensamente, advogava a favor da liberdade incondicional e da justiça para todos. Que "nada contra a maré", sendo, entretanto, consciente dos riscos e consequências até pessoais de seus atos. Em seu sítio pessoal, manuscritos evidenciam seu modo de pensar e fazer teatro: "Teatro só faz sentido quando é uma tribuna livre onde se pode discutir até as últimas consequências os probremas ${ }^{5}$ dos homens. "O ator começa a ficar soberano do seu talento quando ganha conciência de que entra no palco para servir e não para ser servido". No mesmo tom provocativo, o santista com língua de navalha estabelece seu ponto de vista sobre o lugar do artista em referência a complexa questão "estética e autoritarismo": "onde existe autoritarismo o artista é sufocado. O autoritarismo gera o obscurantismo que favorece

4 "INÊS - Você não gostaria que eu fosse o seu espelho? Venha, estou convidando. Senta aqui no meu canapé”. (SARTRE, 2011, p.67).

${ }^{5}$ Em todas as citações será respeitada a grafia original do autor.

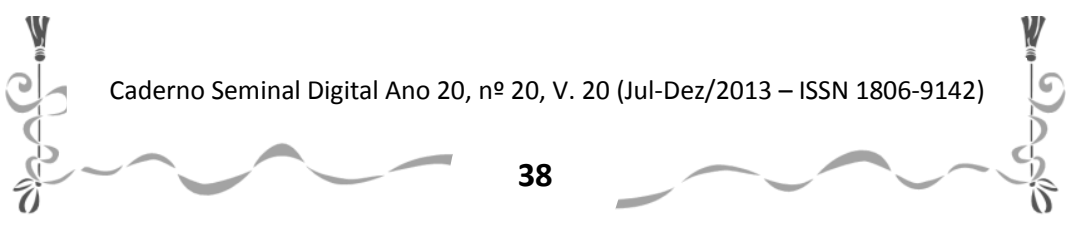


Caderno Seminal Digital

o copiador, o bobo da corte e os senhores da estética decorativa".

A contribuição de Plínio Marcos para a cena cultural brasileira não foi pequena: de mambembe a dramaturgo, ele se posicionou sempre pela liberdade incondicional seja em termos estéticos ou políticos, beirando talvez a anarquia. Foi um renovador do teatro nacional, conviveu com o submundo paulista/santista e de igual modo, conviveu com a elite cultural e intelectual brasileira. Críticos de teatro o aclamaram. Atores consagrados davam notoriedade a seus textos, escritores de peso o defendiam como foi o caso de Clarice Lispector no famoso episódio da defesa do uso dos palavrões no teatro (GOMES, 2007, p.50-60). A própria peça Navalha na Carne tornou-se uma espécie de ícone contra a ditadura e sua nefasta censura, conforme nos esclarece Contreras, Maia, Pinheiro: "Navalha na Carne acabou por se tornar um marco na carreira de Plínio e um marco na luta da classe teatral contra a censura dos militares" (2002, p.59).

Assim, o caso de Plínio Marcos é exemplar como oportunidade para discutirmos o uso da arte como defesa pessoal em momentos de instabilidade e tensão política, ao mesmo tempo em que expõe sua visão da conjuntura social brasileira, carregada de misérias e injustiças, focando em grupos minoritários normalmente desprezados. Plínio Marcos trazia à tona uma abordagem artística transgressora dos
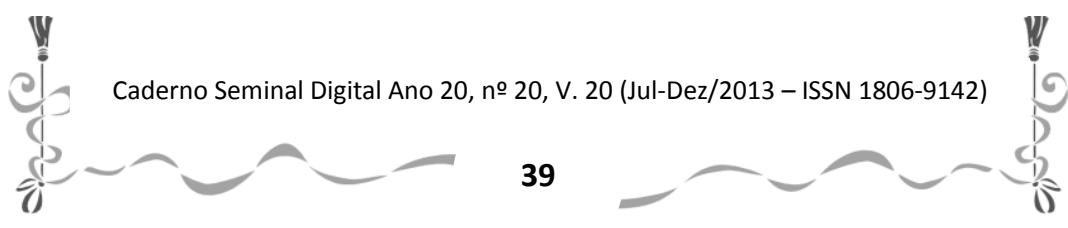
Caderno Seminal Digital

cânones tradicionais que almejava discutir com o povo alguns problemas sociais frequentemente ignorados.

Dava, assim, voz aos esquecidos, se rotulava "repórter de um tempo mau", de um ponto de vista novo, ou seja, não se tratava mais de olhar as misérias nacionais de cima para baixo, restringindo o debate aos círculos culturais elitistas, mas fazer o povo se reconhecer ao conhecer artisticamente a própria realidade. E, de igual modo, estabelecer interlocução com os demais artistas e intelectuais preocupados com uma maior integração cultural do país.

A abordagem social é altamente instigante quando se analisa o teatro de Plínio Marcos, mas pretendemos aqui atingir esse alvo por aproximações entre a peça teatral e a versão fílmica, mostrando o quanto o roteirista/diretor percebeu que tinha em mãos uma obra proponente ${ }^{6}$, ou seja, Plínio deixava muitas propostas temáticas e ações ao optar pela contenção e objetividade na condução do enredo de seus textos. Podemos aventar, neste contexto, uma hipótese de que a dramaturgia pliniana é altamente "roteirizável", ou,

${ }^{6} \mathrm{O}$ conceito de "obra proponente" já foi tratado em artigo anteriormente publicado na Revista "O Eixo e a Roda", número 17, sobre a adaptação fílmica da peça Dois Perdidos numa noite suja, de Plínio Marcos, disponível no seguinte endereço eletrônico:Disponível em $<$ http://www.letras.ufmg.br/poslit/08 publicacoes pgs/Eixo\%20e\%20 a\%20Roda\%2017/01-Andre\%20Luiz\%20Gomes.pdf >. Acessado em 09 de abril de 2013.

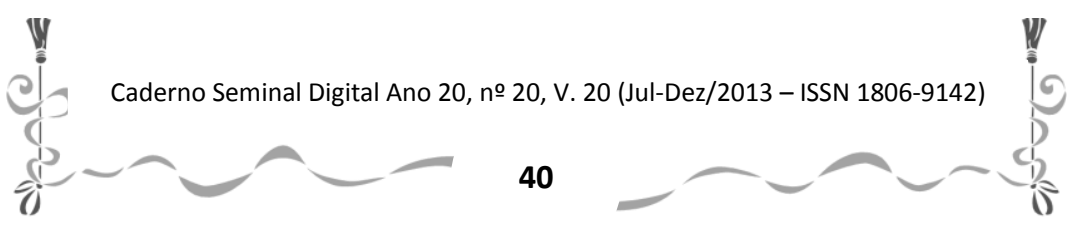


Caderno Seminal Digital

colocando de modo mais audacioso, o seu texto pode ser pensado e estudado como um roteiro cinematográfico de grande potencial para a (re)construção estética de atores e diretores e demais profissionais da sétima arte, prova disto é justamente o volume de filmes realizados a partir de seu teatro.

Para além destes aspectos mais gerais e para restringirmos ainda mais nosso foco, vamos nos limitar a analisar a natureza especular presente no texto teatral e reconstruído imageticamente pelo diretor da versão fílmica.

\section{QUERÔ: ESPELHAMENTOS MALDITOS}

É justamente essa complexidade envolvendo a temática "especular" que nos impulsiona a investigar e apreciar, sob vários ângulos possíveis, o romance Querô uma reportagem maldita, publicado em 1976, adaptado pelo próprio autor, Plínio Marcos, para o teatro em 1979 e transmutado para o cinema em $(2006)^{7}$ sob a direção de Carlos Cortez e roteiro de Bráulio Mantovani e Luiz Bolognesi. Como em qualquer processo de transmutação e, neste caso específico de espelhamentos, "do conto ${ }^{8}$ para o romance e para o teatro e para o cinema", os diferentes suportes

${ }^{7}$ Em 1977, o filme Barra pesada (Direção de Reginaldo Faria) já havia relatado a história de Querô (interpretado por Stepan Nercessian), numa adaptação mais "livre" da obra pliniana.

${ }^{8}$ Segundo Freire (2006, p.78), o personagem surge num conto de Plínio Marcos.

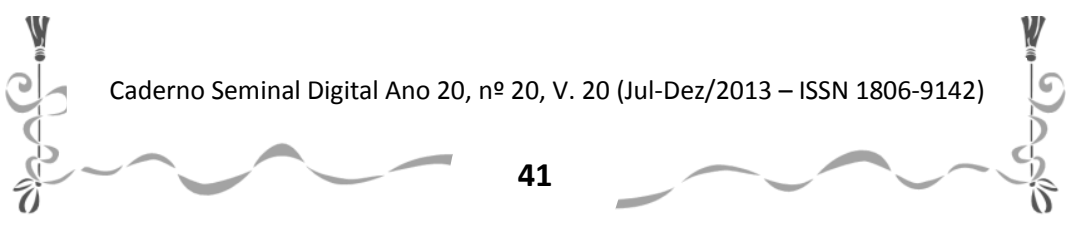


exigiram adaptações do ponto de vista da condução do enredo, inclusive, com inclusão e/ou exclusões de personagens, espaços e ações. E todo esse processo sempre envolve diferentes (re)leituras do texto fonte, que é transcriado pelo dramaturgo-adaptador, pelo diretor, pelo elenco, pelo iluminador e cenógrafo e na transmutação fílmica, envolvendo ainda o roteirista, o diretor, a direção de fotografia etc, ou seja, a transposição cênica ou fílmica será, geralmente, resultado de uma (trans)criação coletiva. Ainda neste horizonte, o cineasta concebeu sua leitura da peça/romance com um aspecto bastante peculiar: as cenas são entremeadas por lapsos de silêncio que, imageticamente, são vistos num plano escuro, dando a impressão que as cenas são pedaços de relatos jornalísticos, ou reportagens compondo um quadro da realidade e ainda nos remete aos atos de um texto teatral, sendo que, curiosamente, na peça homônima de Plínio não há divisão em atos.

Sem nos aprofundarmos nas questões teóricas sobre adaptação/transcriação, nosso objetivo é discutir o romance e, sobretudo, a peça teatral de Plínio Marcos como obra proponente, ou seja, texto que traz no não dito, nas rubricas, nas falas, na construção das personagens propostas para transposições cênicas/fílmicas sob a égide do espelhamento, tanto do ponto de vista do uso estético do vidro refletor por parte do romancista/dramaturgo e do diretor da película, quanto das metáforas passíveis de se interpretar, inclusive em

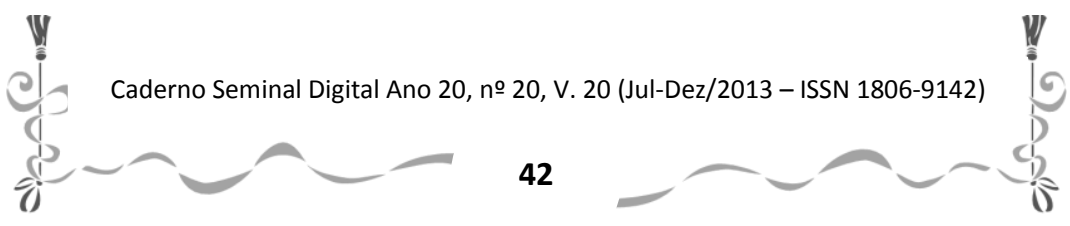


perspectiva relacional, as personagens das obras. Uma das características do texto pliniano é a forma objetiva e direta de apresentar e desenvolver seus dramas - contenção, tensão, intensidade, e densidade, como apontam alguns críticos. (Cf. MICHALSKI, 2004, p.98; ZANOTTO, 2003, p.11; MAGALDI, 2001, p.385). Essa contenção faz com que o texto de Plínio Marcos deixe na entrelinha, no detalhe, no hiato muitos desdobramentos, que a ação dramática pode adquirir e o adaptador/transcriador, como estudioso perspicaz, pode evidenciar, colocar em primeiro plano e até ampliar.

No romance, a reportagem maldita é conduzida pelo narrador-repórter numa espécie de romance-documentário. $\mathrm{Na}$ peça, o repórter, como pede a rubrica, "dirigindo-se ao público, em tom de narrativa" (MARCOS, 2003, p.237), afirma que "o chefe de reportagem do jornal o escalou para fazer a cobertura" do crime do cabaré "Leite da mulher amada", onde um menor de idade matara um policial e ferira outro. Mas, o repórter quer entrevistar o pivete para entender como e porque ele foi levado ao mundo da criminalidade.

No filme, não temos o repórter conduzindo as ações. 0 enredo é construído, principalmente, em primeira pessoa por Querô e também pelas personagens secundárias e pelos interrogatórios dos policiais. Na peça teatral, o presente e o passado se confundem, pois, na medida em que o repórter lança uma pergunta, fatos são revividos de forma fragmentada e sobrepostos pelo pivete. $O$ diretor,

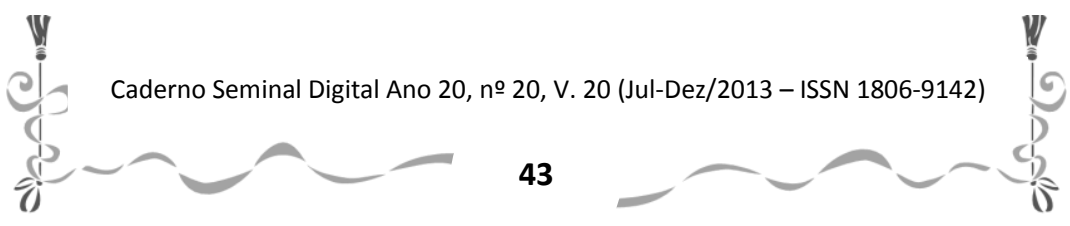


Caderno Seminal Digital

a

obviamente, se utilizou de recursos fílmicos como a sobreposição de imagens rápidas, contínuas, fragmentadas e sobrepostas para presentificar o passado e, ao mesmo tempo, construir imageticamente a perturbação mental e condição social de Querô, filho de uma prostituta, que foi expulsa do bordel em que trabalhava no dia em que deu à luz ao menino. Desesperada, ela se suicida tomando querosene. Violeta, a dona do prostíbulo, decide cuidar do garoto e o apelida de "Querô", em referência ao modo como sua mãe morreu. Ao crescer, o pivete, revoltado com os maus tratos que recebe, passa a cometer pequenos delitos. Um dia ele é pego e encaminhado à FEBEM, onde sua vida é marcada para sempre.

Esse breve resumo do enredo nos remete ao universo teatral pliniano. A escola de Plínio Marcos era a rua, a sua "quebrada do mundaréu" e, obviamente, o palco teatral. Um sujeito que "camelava" suas peças em plena hasta pública, mantendo um contato direto com o povo, pagando conscientemente o preço de tal atitude, conduta que viria a reaparecer na cena cultural brasileira com a eclosão dos ditos "escritores marginais".

Querô - uma reportagem maldita (1976 e 1979), seja o romance, o texto teatral ou a película, traz uma gama de situações para se analisar a natureza do olhar dos personagens nas múltiplas direções, sobretudo em razão da clausura que todos experimentam. Essa clausura realça elementos de especulações e construções identitárias tendo

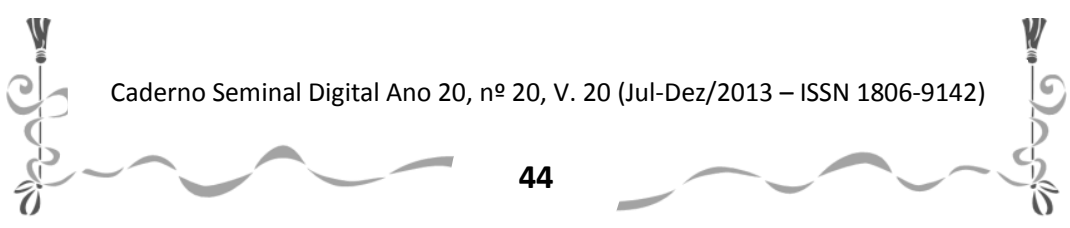


Caderno Seminal Digital

a

em vista as relações sociais estabelecidas, degradantes entre sujeitos marginais e marginalizados. A presença e importância de espelhos na constituição do filme Querô são evidentes e, desde logo, percebemos que este objeto semanticamente riquíssimo não surge inutilmente na composição da cena pliniana.

Pode-se aventar que sujeitos marginalizados cafetões, prostitutas e michês - são pensadores de sua própria existência e que, portanto, especulam sobre a natureza do ser, sobre as inconsistências da condição humana frente a um mundo cruel e sem saída digna possível.

Veremos que na peça e filme, a especulação serve mais a infelicidade que a felicidade, sobretudo pelas mudanças modernas de percepção em relação ao ato contemplativo. Os "espelhos modernos" servem mais para esconder do que para mostrar. Servem mais para o turvamento da identidade e da existência. Enganam e iludem ou no máximo exibem a dura realidade fática, fatídica e (in)existencial. Esta orientação contemplativa/especulativa entra em choque com a visão aristotélica, pois segundo o pensador grego:

A felicidade tem, por conseguinte, as mesmas fronteiras que a contemplação, e os que estão na mais plena posse desta última são os mais genuinamente felizes, não como simples concomitante, mas em virtude da própria contemplação, pois que esta é preciosa em si mesma. $\mathrm{E}$ assim, a felicidade deve ser alguma forma de contemplação. (1991, p.237)

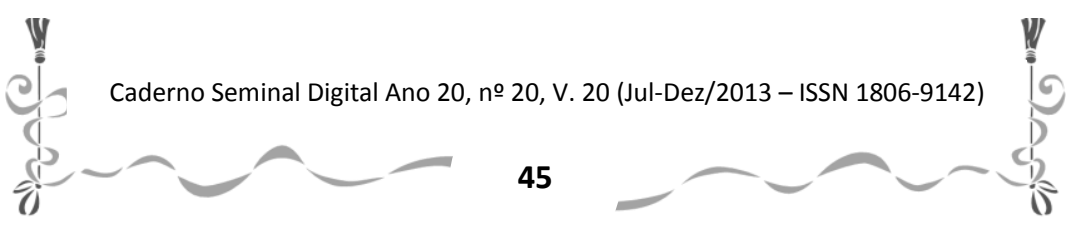


Em Navalha na carne, outro texto pliniano seminal, por exemplo, observemos a descrição inicial do cenário e da ambiência, que apesar de lacônica, não deixa de trazer o espelho e não qualquer espelho mais um de "corpo inteiro": "Um sórdido quarto de hotel de quinta classe. Um guardaroupa bem velho, com espelho de corpo inteiro, uma cama de casal, um criado mudo, uma cadeira velha são os móveis do quarto" (MARCOS, 2003, p.138). Nesta peça do autor santista, a presença do espelho inicialmente serve para que haja um autorreconhecimento das personagens (especialmente Neusa Sueli e Veludo) da própria situação decrépita a qual estão submetidos.

A preocupação com a própria aparência é uma das mais enfatizadas características de Leda, mãe de Querô, que, como Neusa Sueli, trabalha como prostituta, vende seu corpo e, nessa direção, olhar-se no espelho parece ser um de seus poucos luxos, conforme observamos na rubrica abaixo:

A luz começa a piscar e a girar. No outro canto do palco aparece Leda, sentada diante de um espelho cheio de lâmpadas, como de um camarim. Ela está muito bem vestida e arrumada. Vira-se para Querô e canta sedutora. (MARCOS, 2003, p.256)

Há que percebermos também que, oniricamente, Leda estabelece um diálogo com seu filho e vice-versa. Isso parece ser possivel, inclusive, porque o espelho surge como uma espécie de portal para transitar entre os mundos dos vivos e

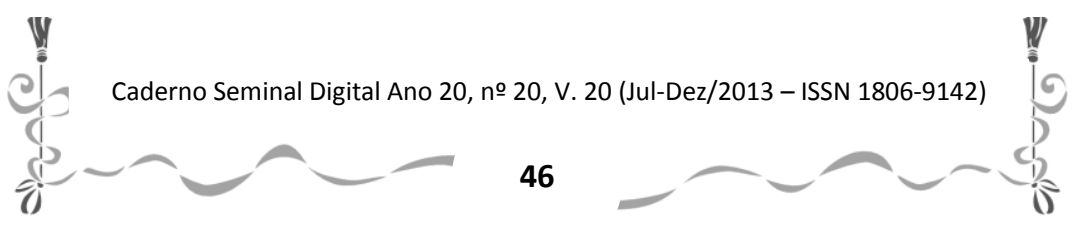


dos mortos. Este procedimento narrativo-imagético também é usado pelo diretor do filme, de sorte que a última visão de Quero, ferido e cambaleante, é justamente de sua mãe em plena "viração". Este momento do filme é magistral, pois condensa nascimento e morte de Querô em perspectiva espelhada, bem como, ressurreição e início do trágico fim de sua mãe, pois, a vinda de Querô ao mundo resultou no fim de Leda. Assim, notamos, ao longo das trajetórias de vida e morte de Leda e seu desventurado filho, uma simetria. Portanto são espelhos simetricamente construídos e destruídos por contingências de ordem social e econômica, mas também por escolhas pessoais, tendo em vista as possibilidades que a liberdade, numa visão sartriana, oferece aos sujeitos históricos.

Outra simetria entre Leda e Querô é notada pelo relato da mãe a seu filho sobre a fúria dos seus clientes durante os programas: "Todas as noites eles vinham em bando, como os porcos andam na floresta (...) mordiam meu corpo, cuspiam suas aflições no meu ventre, babavam como porcos que eram" (MARCOS, 2003, p.257). Situação muito semelhante ocorre com Querô no filme no momento da violência sexual coletiva sofrida por ele no seu quarto de reformatório, a qual não sai de sua cabeça e que na obra fílmica é traduzida em flashbacks, especialmente no momento em que Naná tenta consumar o programa forçado com Querô; a partir daí o

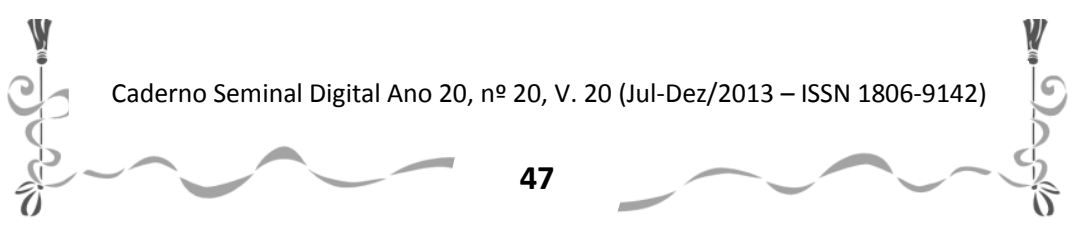


Caderno Seminal Digital

Â.

menino é tomado de uma fúria implacável e destrói o "escritório" de Naná.

No texto teatral, uma passagem que oferece exatamente um diálogo espelhado entre os mundos de Querô e Leda é justamente a resposta de Leda ao questionamento máximo de Querô do motivo dela ter permitido o seu nascimento. Leda, ledamente, pede perdão ao seu primogênito, justificando que a vida atroz da prostituição não permitiu que ela o visse crescer, para quem sabe, mudarem de vida (MARCOS, 2003, p.257).

Sob o amargor causticante do querosene ingerido por Leda, há uma característica espelhada em Querô que constantemente o persegue, a secura de sua boca, sua sede que parece não ter fim - ele está sempre em busca de água, especialmente nos momentos de agonia, ferimentos com grandes perdas de sangue (MARCOS, 2003, p.272).

De modo similar, mãe e filho foram hostilizados e explorados impiedosamente por Violeta, a cafetina, em moldes semelhantes ao que se processa em Navalha na carne no bojo da relação de Neusa Sueli e Vado, o seu cafetãoamante

O tom de crueldade de Violeta é crescente e, como em outros personagens plinianos, ela mantém essa frieza até as últimas consequências, mas se revela emotiva quando Ju a acusa de responsável pelo suicídio de Leda.

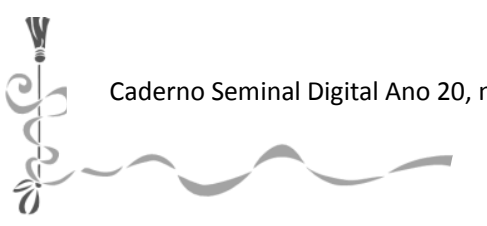

48

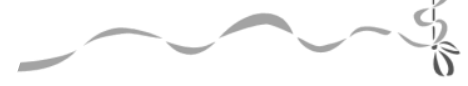


Na peça, apesar de toda a frieza e maldade da cafetina, Leda reconhece que, no fundo, Violeta é uma boa mulher e resolve deixar o filho justamente para ela criar. O dramaturgo também evidencia essa característica em rubrica: As mulheres relaxam e se afastam, ficando uma ao lado da outra. (Violeta então levanta a criança como se a mostrasse a Deus). Esse conflito interno de Violeta, esse papel de cafetina fria e sem escrúpulos, na verdade esconde a mulher sofrida pela vida solitária e explorada de prostituta. No filme, Violeta descarrega sua raiva contra Leda, ironiza sua condição de grávida, acusa as "meninas" de um bando de românticas e se dirige ao seu quarto e sozinha fica em frente ao espelho, para o qual ela não olha diretamente. $E$ o espectador vê a imagem desdobrada em duas. Além do olhar da atriz, Ângela leal, que constrói a angústia e a indecisão da personagem, o espelhamento desdobrado é recurso imagético para evidenciar as duas Violetas - a ressecada pela vida - como um tipo de Paulo Onório, que reavaliando a sua vida, dissesse: Foi essa vida de cafetina e prostituta que a tornou fria e profissional para com o outro, e a ressentida, triste figura capaz de acolher e se preocupar com o futuro daquela criatura inocente que agora habitaria nosso mundo de cão (MARCOS, 2003, p.243).

Esse desdobramento é ainda mais evidente em Querô, que ganhou esse apelido porque a mãe se suicidou tomando querosene, por isso é tratado por alguns por Querô, por

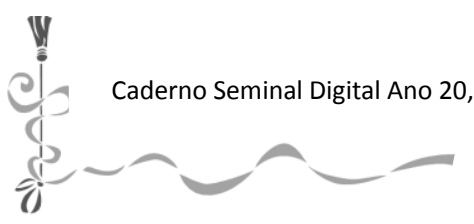

49

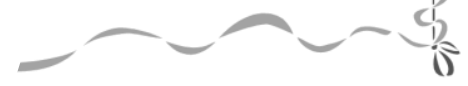


Caderno Seminal Digital

î.

outros por Querosene enquanto, na verdade, se chama Jerônimo da Paixão (no filme é Jerônimo da Piedade). Jerônimo em grego significa "nome sagrado", assim, o seu sobrenome da Paixão também reforça a vida em calvário de Querô, de seu sofrimento em crescendo. Em interrogatório, o policial pergunta, na peça, pelo seu nome e, numa forma de construção da imagem de outro pivete, Nelsão intervém:

DELEGADO: Seu nome.

QUERÔ: Jerônimo da Paixão.

DELEGADO: Tem apelido.

QUERÔ: Querô.

NELSÃO: Querô, o caralho! Teu apelido é Querosene. Ele é Querosene porque a mãe se empapuçou de querosene e morreu (Ri muito).

Querô vai para o reformatório e essa fala de Nelsão no filme é colocada na boca de um dos meninos internos e Querô vira chacota de todos os internos e, a partir daí, a sua condição de oprimido se intensifica quando a violência verbal e sexual atinge um grau insuportável. Acusado de ter furtado um gringo, Querô fica no reformatório e é obrigado a seguir e a obedecer à lei da violência e as ameaças dos outros pivetes e dos que cuidam do reformatório vão aumentando. No filme, planos de baixo para cima reproduzem imageticamente esse mundo opressivo e opressor: Querô aparece lavando um banheiro minúsculo e imundo; em uma cela escura, a direção aproveita uma luz que ilumina, através de uma janela

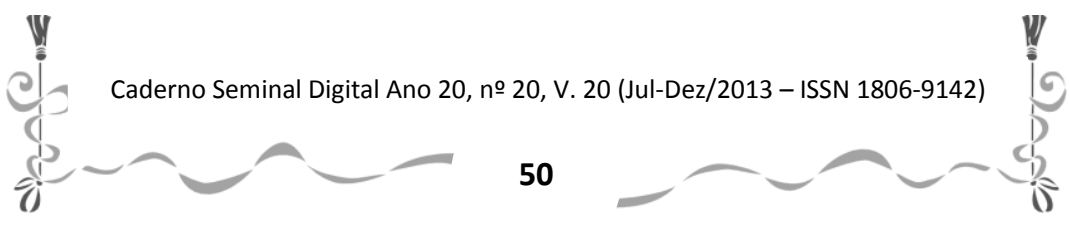


gradeada, o rosto de Querô e aproxima a câmera nas baratas que passam pelo seu corpo. Nesse ambiente escuro e imundo, Mosca, outro interno, se aproxima da janela, num jogo irônico e ameaçador, diz o que ele e os outros pensam. Querô, transformando-se naquele momento em um espelho distorcido e denunciador: “- MOSCA: Ai... tu pensa que tu é valentão... Mas os caras vão comer seu cu e te chamar de Querosene... seu viadinho...".

No plano da continuidade da vida prostituída de sua mãe Leda, Querô é alvo da sanha sexual dos demais internos, especialmente dos líderes e donos do poder daquele microcosmo em que se estabelecem novas formas de autoridades paralelas entre os jovens. O mais interessante é ver, deste modo, a relação espelhada que se dá entre a trajetória de vida de Leda e Querô, este agora é sujeito prostituído e objeto da lascívia dos demais delinquentes juvenis. O próprio nome que Jerônimo recebe da vida, por imposição da morte bizarra de sua mãe, retrata este espelhamento sombrio, que jamais o deixará esquecer sua triste linhagem. Os internos o desejam justamente porque é notória e sobejamente conhecida a história de sua genitora, puta suicida com um porre de querosene. Ainda prolongando um pouco mais esta perspectiva espelhada, podemos ver inclusive o reformatório como uma "zona", um prostíbulo, mas que agora serve também para liberar as perversões e o ódio de meninos excluídos socialmente e que se excluem

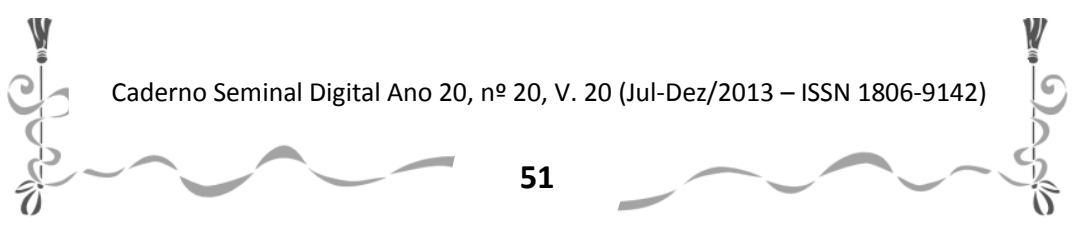


Caderno Seminal Digital

a

entre eles mesmos, forçando o nascimento de meninos-puta, verdadeiros escravos sexuais, o que não está totalmente diferente do que se processou com Leda, escravizada por Violeta (MARCOS, 2003, p.242-243).

No reformatório, Querô reproduz a imagem que ele vê e logo lidera e mata um policial e encabeça uma fuga do reformatório. Na reprodução fílmica da cena da fuga, Querô passa pelos muros do reformatório, mas cai no lamaçal e é obrigado por ali caminhar com dificuldade e se lambuzando de lama numa metáfora explícita de sua condição de assassino e fugitivo.

No filme, Querô busca abrigo na casa de Naná ${ }^{9}$, um homossexual que vive numa casa de prostituição. A personagem é interpretada de forma extremamente estereotipada, com todos os trejeitos de uma "bichinha" que promete arrumar comida para Querô, mas exige como troca que Querô o faça de sua mulher naquela noite. A prostituição como moeda de troca, a masculinidade anteriormente atingida pelo estupro sofrido no reformatório e sua condição

9 Há que se rememorar Naná (1880), romance de Émile Zola, a personagem que dá nome ao romance é justamente uma atriz fracassada que ganha a vida se prostituindo na corte de Napoleão III. Na obra pliniana, temos uma Naná espelhada ao reverso, pois se trata de um homossexual que almeja prostituir Querô, em ambiente diametralmente oposto, no submundo dos miseráveis. Observe-se que no quadro de Manet, Naná está exata e curiosamente defronte a um espelho.

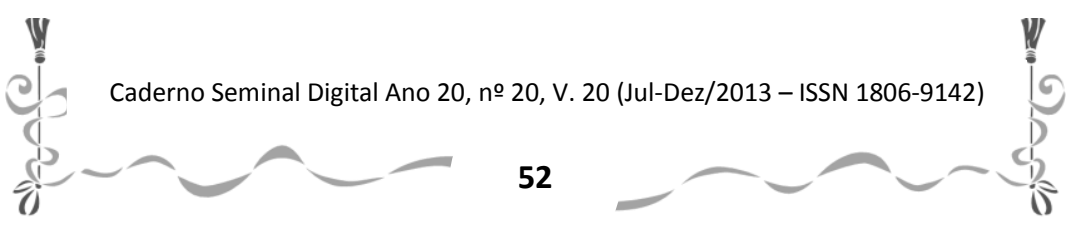


de michê fragilizam ainda mais Querô, que, em delírio, quebra os móveis e objetos do quarto de Naná e, entre eles, um grande espelho e, num plano de cena, temos a imagem de Querô reproduzida nos cacos de espelho estilhaçado, metaforizando sua existência quebrantada e ao mesmo simbolizando a ruptura de um ciclo nefasto de exploração sexual e econômica, pois Naná propõe sexo em troca de comida.

Este episódio com Naná traz a lume novamente sua trajetória espelhada com Leda, sua mãe, pois mais uma vez a vida Ihe impinge a necessidade de se prostituir para viver.

Querô não aceita, portanto, levar uma relação de troca, de prostituição e vai até a casa de Ju, uma antiga vizinha, que se revela extremamente solidária e generosa. Uma mulher religiosa que acaba o convencendo a ir a um dos cultos. Lá Querô conhece Lia, personagem presente apenas no romance. Lia é uma jovem cantora do coral da igreja e por ela ele se apaixona. E no dia do aniversário de Lia, resolve comprar um presente, mas não tem dinheiro. Lia o trata de Jerônimo e, por ser assim chamado e tratado com carinho, Querô se vê como outro - naquele momento ele é o Jerônimo de Lia. Resolve jogar para ganhar o que precisa para pagar o presente. Perde tudo no jogo e se endivida. Desnorteado volta a furtar, reencontra, numa boate, o outro policial, Sarará. Antes passa pelo banheiro e se olha no espelho, mas o posicionamento dos espelhos reproduzem

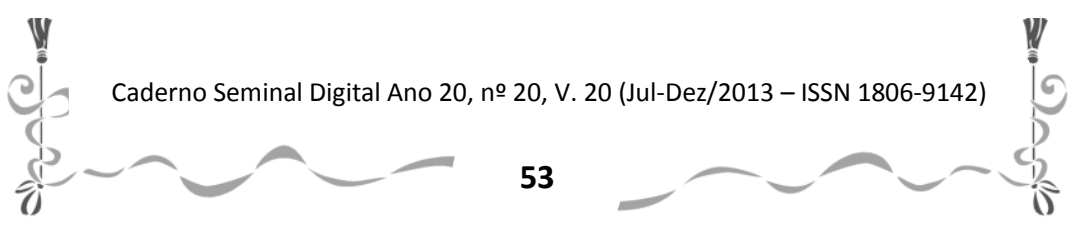


Caderno Seminal Digital

caleidoscopicamente várias imagens de Querô, que decido, mata Sarará e sai ferido.

A cena que inicia o filme é a mesma que o encerra: Querô andando em passo rápido, estonteante e ferido, tendo momentos de delírio em que vê sua mãe. $O$ filme reproduz o que é pedido na rubrica do texto teatral (MARCOS, 2003, p.256) e a sanha de Leda por gerar seu filho, sua única joia é embalado por suas palavras elegíacas. $O$ ato de olhar, de ver no outro, ou de se imaginar a partir do que o outro diz, refletindo as inquietudes, os desejos e a angústia das personagens, também provoca terror, medo, compaixão e, no caso da peça pliniana, desprezo, menosprezo, prazer sadismo, arrependimento, resultando num jogo entre opressores e oprimidos.

Os espelhos no filme Querô exorbitam a realidade, denunciam e servem de meio de exercer a opressão. Os espelhos funcionam como uma verdade inescapável num mundo pliniano em que Jerônimos, Querôs e Querosenes buscam incansavelmente outras imagens, mas fogem de suas ruínas existenciais.

\section{“O HOMEM ESTÁ CONDENADO A SER LIVRE”}

A mãe de Querô, apesar de ter sido encarcerada pela vida no prostíbulo de Violeta, mostrou que a máxima sartriana da liberdade humana inarredável tem sua validade para qualquer ser humano. Sua opção e escolha pelo suicídio foi

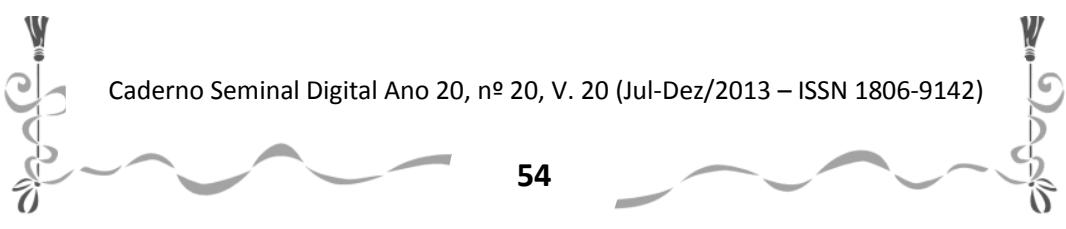


Caderno Seminal Digital

î.

prova cabal de que somente ela detinha os rumos últimos de sua existência. Por mais que lhe falassem para desistir de ser mãe, para abortar, ela provou que puta pode sim ser mãe. Segundo Sartre, a única coisa impossível para o homem é deixar de ser livre. Somos assim, livres para escolhermos nosso projeto de vida, incluindo aí a morte. A liberdade é condição sine qua non da existência sartriana, o paradoxo é que estamos condenados a esta libertação:

Estou condenado a existir para sempre para além da minha essência, para além dos móbeis e motivos do meu ato: estou condenado a ser livre. Significa que não se poderia encontrar outros limites à minha liberdade para além da própria liberdade, ou, se preferirmos, que não somos livres para deixar de ser livres. (Sartre, 1998, p.494)

A nossa consciência é nossa liberdade, de acordo com Sartre. Querô (na película) mesmo enclausurado numa solitária da FEBEM medita, especula e traz à tona sua consciência e cria um projeto, qual seja: "Mas eu vou arrumar uma arma, por essa luz que me ilumina. Eu vou ser o Querô, a zorra encarnada, eu vou mandar ver, mãe. A senhora vai ver" (na peça o dramaturgo optou por um diálogo mais explícito entre Leda e Querô). Esta conclusão vem após questionar o projeto de Leda, o de tê-lo; afinal, segundo Querô, de que serviu ter nascido para levar aquela vida de esmola e de favores: "Por que, mãe? Por que tu me pôs no mundo? Olha que tu fez comigo, mãe! Porra mãe! Eu nunca fui nada sempre me fudi! Vivo de favor, durmo de favor, como de esmola! Isso

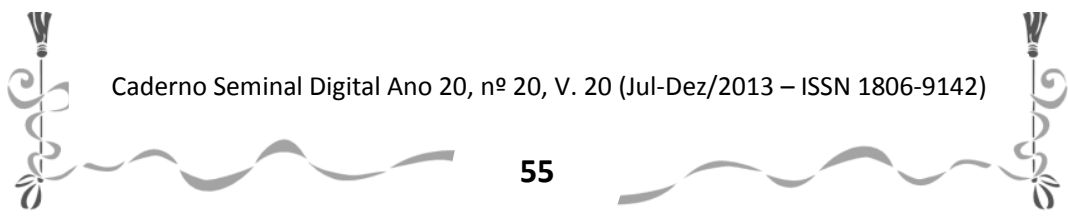


î.

\section{Caderno Seminal Digital}

Caderno Seminal Digital

presta, mãe? Isso acaba com a gente! Deixa a gente ruim, mãe!". Vejamos como Silva se pronuncia acerca do conceito sartriano de projeto, o qual orienta nossa análise:

De alguma maneira, meu projeto fundamental é criar-me com em-si e, dessa forma, revelar-me totalmente a mim mesmo. Como é por minhas escolhas que o mundo se revela, uma escolha primordial de mim mesmo seria a revelação absoluta de mim mesmo. (2004, p.139-140)

Ao fim do filme, Leda reaparece e tem seu encontro com Querô, ambos olham-se fixa e penetrantemente e, em transe, Querô reconhece sua mãe no meio das demais putas. A feição de Leda é aterradora e não dá mostras de horizonte otimista ao filho. A tristeza é a tônica de seu olhar. $\mathrm{O}$ seu rosto em nada difere da palidez cadavérica das cenas iniciais do filme. É para ambos o fim. O filme, portanto, dialoga de modo seletivo, inclusive com falas, gírias e tempo histórico, atualizados, à luz de suas intenções estéticas tanto com passagens do romance, tanto com o texto teatral, de modo a criar um mosaico entre as diferentes perspectivas das três formas artísticas de um Querô escrito, encenado, filmado, e por que não dizer, espelhado, através da belíssima atuação do jovem ator Maxwell Nascimento.

\section{REFERÊNCIAS BIBLIOGRÁFICAS:}

ARISTÓTELES. Ética a Nicômaco. Tradução Leonel Vallandrano e Gerd Bornheim. São Paulo: Nova Cultural, 1991.

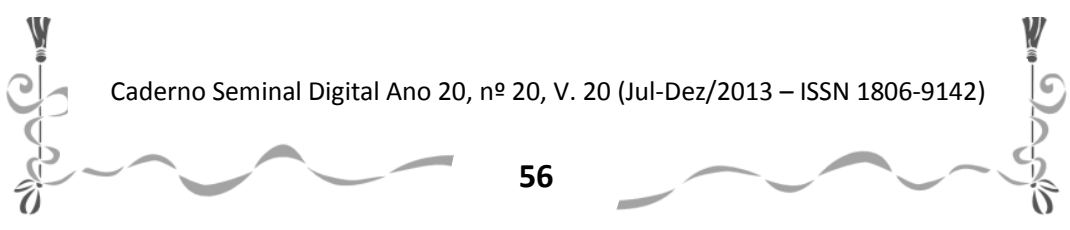


Caderno Seminal Digital

就

CARROLL, Lewis. Alice no País das Maravilhas. 9ed. Tradução e adaptação de Monteiro Lobato. São Paulo: Brasiliense, 1960.

CONTRERAS, Javier Arancibia; PINHEIRO; Vinícius; MAIA, Fred. Plínio Marcos: a crônica dos que não têm voz. São Paulo: Boitempo, 2002.

FERREIRA, Eliza R. Espelhos de papel: um espelhamento entre Machado e Tchekov. (Dissertação de Mestrado em Estudos Literários). UNESP Araraquara/São Paulo, 2001.

FREIRE, Rafael de Luna. Atalhos e Quebradas: Plínio Marcos e o cinema brasileiro. (Dissertação de Mestrado em Comunicação, Imagem e Informação) UFF, Niterói, 2006.

GENETTE, Gerard. Figuras. São Paulo: Perspectiva, 1972.

GOMES, André Luís. O Teatro de Plínio Marcos no cinema. Anais do XI Congresso Internacional da ABRALIC Tessituras, Interações, Convergências, São Paulo, 2008.

. Clarice em cena. Brasília: EdUnB, FINATEC, 2007.

GRIMM, Jacob; GRIMM, Wilhelm. Contos de Grimm - Branca de Neve. 6ed. Tradução Lenice Bueno da Silva. São Paulo: Ática, 1996.

MAGALDI, Sábato; VARGAS, Maria Thereza. Cem anos de teatro em São Paulo (1875-1974). São Paulo: SENAC, 2001.

MARCOS, Plínio. "Querô" In: Melhor Teatro - Plínio Marcos. Seleção e Prefácio de Ilka Marinho Zanotto. São Paulo: Global, 2003.

. Navalha na carne e Quando as máquinas param. São Paulo:

Parma, 1984.

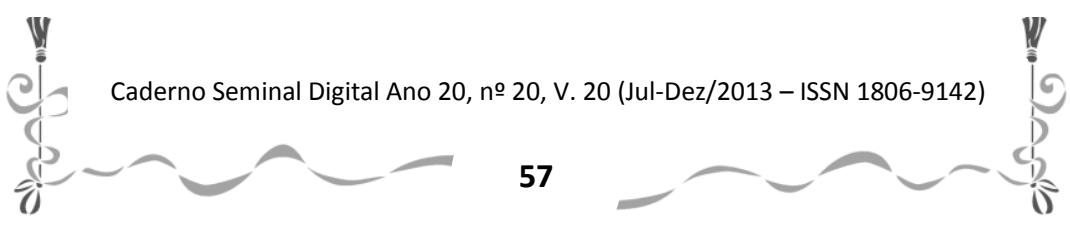


MICHALSKI, Yan. O teatro sob pressão. Uma frente de resistência. Rio de Janeiro: Zahar, 2004.

SARTRE, Jean-Paul. Entre quatro paredes. 6ed. Tradução Alcione Araújo e Pedro Hussak. Rio de Janeiro, Civilização Brasileira, 2011. . O Ser e o Nada: Ensaio de Ontologia Fenomenológica. 6ed. Tradução Paulo Perdigão. Petrópolis: Vozes, 1998.

SILVA, Franklin Leopoldo. Ética e literatura em Sartre: ensaios introdutórios. São Paulo: Editora da UNESP, 2004.

ZANOTTO, Ilka. Descida aos Infernos. In: MARCOS, Plínio. Melhor Teatro - Plínio Marcos. Seleção e Prefácio de Ilka Marinho Zanotto. São Paulo: Global, 2003. pp.7-20. 